\title{
Sławomir Kadrow*
}

\section{JANUSZ KRUK'S SETTLEMENT ARCHAEOLOGY: INTELLECTUAL INSPIRATIONS AND DETERMINANTS}

\begin{abstract}
Kadrow S. 2020. Janusz Kruk's settlement archaeology: intellectual inspirations and determinants. Sprawozdania Archeologiczne 72/1, 31-45.

This article is dedicated to the inspirations and intellectual determining factors of Janusz Kruk's settlement archaeology. For this purpose, the article focuses on the well-known literary theory of "the Death of the Author". It has been assumed that Kruk's scientific output should be assessed in the light of his most important work - and not his last work. Kruk's scientific output is dominated by the view that functional relations between settlement, economy, and natural environment are of key importance for the historical process. Equally vital is the opinion that settlement, economic, and environmental changes are affected by human influence on the natural environment (anthropopressure), inspired indirectly by George Perkins Marsh and directly by the first report of the Club of Rome. Janusz Kruk's settlement archaeology is permeated by the principles of functionalism, but its originality is determined by the presence of the elements of "geographical possibilism".
\end{abstract}

Keywords: Janusz Kruk, settlement archaeology, anthropopressure, natural environment, economy Received: 21.01.2020; Revised: 09.04.2020; Accepted: 19.05.2020

The settlement network and material remains of the south-eastern group of the Funnel Beaker culture play an important role in Janusz Kruk's settlement archaeology (Fig. 1). In the context of that group and the entire culture, the settlement complex in Bronocice (Fig. 2) may be considered as the icing on the cake. This is a sufficient reason to attempt

* Institute of Archaeology Rzeszów University, Moniuszki st. 10, 35-015 Rzeszów, Poland; slawek.kadrow@ archeologia.rzeszow.pl 


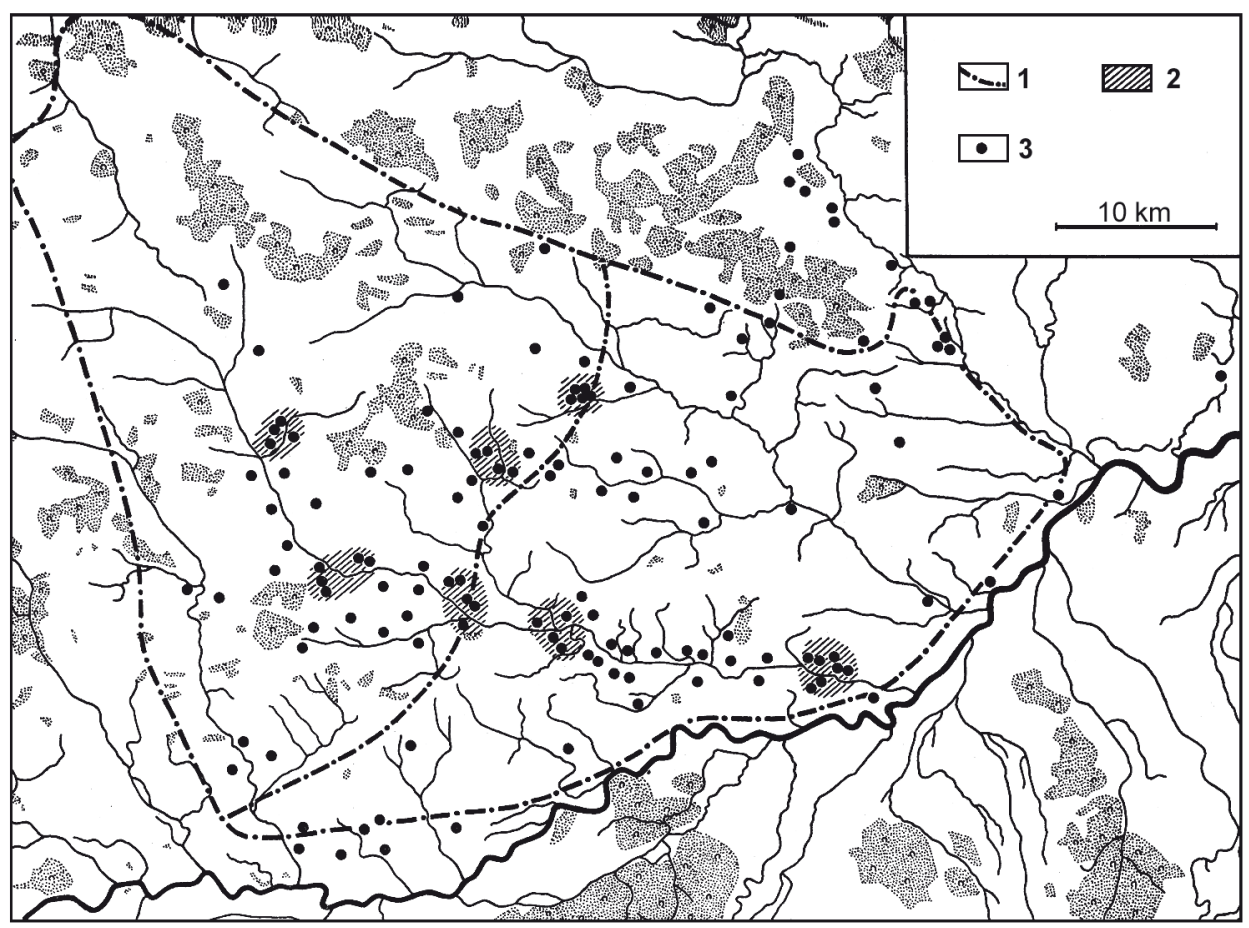

Fig. 1. SW part of the Niecka Nidziańska region. Settlement of the Funnel Beaker culture; 1 - subregion borders, 2 - settlement points, 3 - selected settlement agglomerations (acc. to Kruk 1973)

a reconstruction of that trend of studying settlement networks in research in the present volume. An even more important reason for the considerations in this article is the ongoing discussion on the theoretical and source-related aspects of this kind of settlement study, primarily in Polish archeology ( $c f$. Kadrow 2010; Włodarczak 2013; Diachenko et al. 2016). There is no indication that this discussion will soon end. It must of course be admitted that this topic in archeology is already beyond international popularity ( $c f$. Howell 1983; Bintliff 2013, 21, 22).

I have already proposed an interpretation of Janusz Kruk's settlement archaeology and its selected elements in several papers (Kadrow 1992; 2010; 2013; Kadrow and Machnik 2001). But now, for the first time, I am going to examine its intellectual determinants and inspirations.

My attempted reconstruction of Janusz Kruk's settlement archaeology will be based solely on my analysis of his publications. I want to resist the temptation of directly questioning the researcher about the sources of his inspiration or the meaning, significance and circumstances of his achievements. The debate between Jan Machnik (2015; Woźny 2014) and Sarunas Milisauskas (2015), important participants in the Polish-American research 


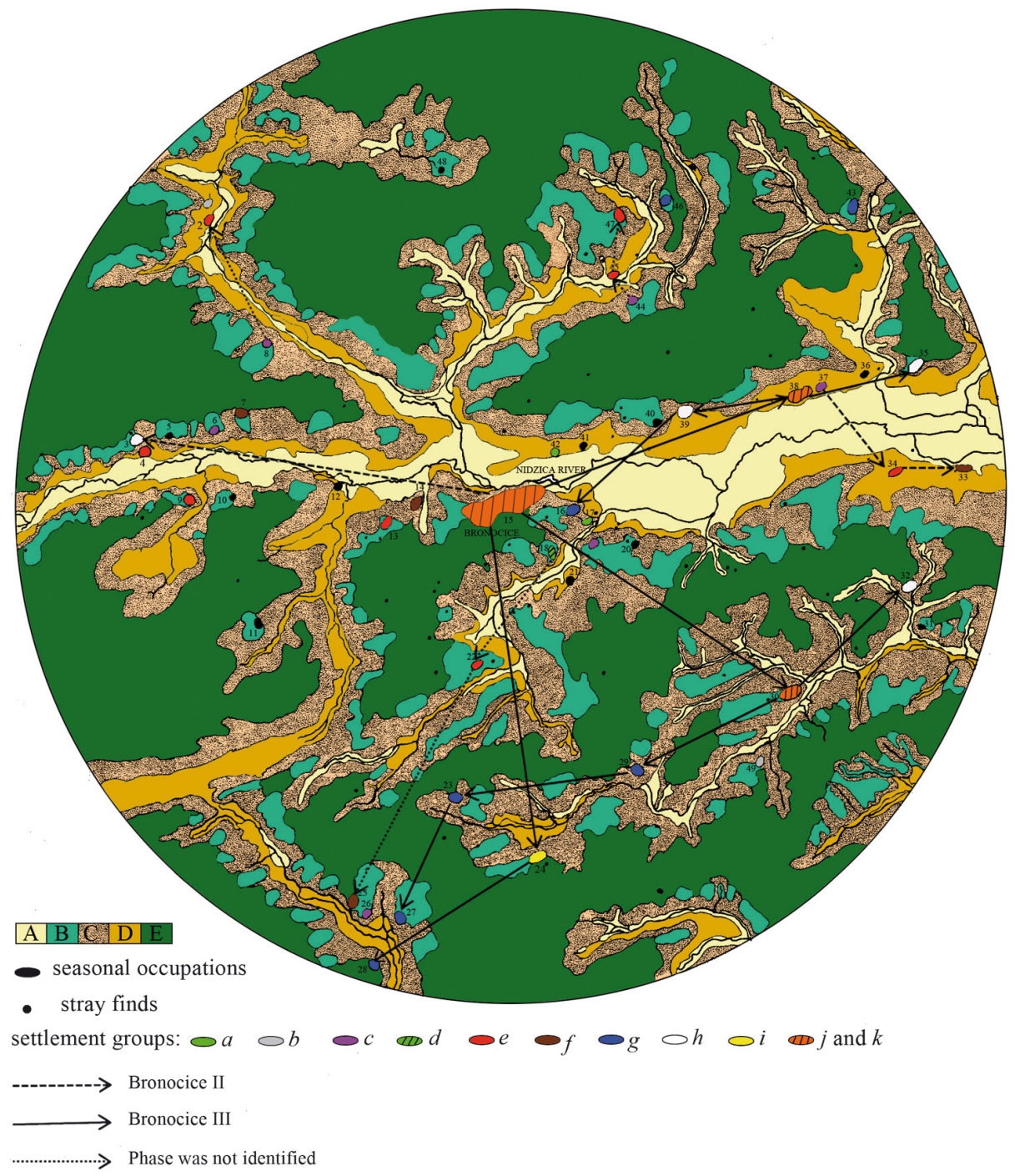

Fig. 2. Settlements of the FBC. 'Circle' with ecological zones in an area of $10 \mathrm{~km}$ around the Bronocice site. $\mathrm{A}$ - alluvial zone, $\mathrm{B}$ - valley edge zone, $\mathrm{C}$ - slopes of the upland zone, $\mathrm{D}$ - edges of the upland zone, $\mathrm{F}$ - upland zone; Settlement size: $a-1.80$ ha; $b-2.00$ ha; $c-2.20-2.30$ ha; $d-2.50$ ha; $e-2.70-3.10$ ha; $f-3.40-3.70$ ha; g- 4.00-4.50 ha; h- 5.00-5.10 ha; I - 5.60 ha; j - 8-9 ha; k- 21 ha (acc. to Diachenko et al. 2016)

project from 1966-1978, is related directly to the issues discussed here, and is quite instructive in itself, as it has shown the distinct disparity in their opinions on certain aspects of the project. This suggests that the accounts of people engaged directly in an event may be marked by subjectivity and ambiguous assessments. 
For this reason, I have turned to the theory of "the Death of the Author" known from literary criticism ( $c f$. Barthes 2006), which opposes the view equating the significance of a text with the author's intention. The same stance has been taken by Russian formalism, American New Criticism and French structuralism (Compagnon 2010, 39-42). In literature, the theory means that the most important element in the sequence "the author - the work - the reader/critic" is the work, and its significance is interpreted by the reader or the critic. By analogy, the most important element in the sequence "the producer - material culture - the archaeologist", is material culture, whose significance is decoded by the archaeologist. The theory of "the Death of the Author" seems an apt illustration of the cognitive potential of archaeology.

However, my approach, i.e. omitting the inquiry about the author's presumable intentions, has been inspired most directly by the distinctive version of "the Death of the Author" theory as presented in Marcel Reich-Ranicki's autobiography Mein Leben (1999). This version proved so controversial that it evoked a response from Martin Walser (2002), who maliciously interpreted Reich-Ranicki's achievement in his novel Tod eines Kritikers.

In December 1952, Reich-Ranicki had a two-hour conversation with Anna Seghers in Warsaw. He praised the composition of her novel Das siebte Kreuz. Seghers disagreed with him because, in her view, the composition was what she had taken from Alessandro Manzoni's novel Die Verlobten. Reich-Ranicki read Manzoni’s book the following week, finding there no analogies worth noting. The book had made a great impression on Seghers, but its function as a model for Das siebte Kreuz was obvious only to her. Reich-Ranicki began to think that Seghers did not understand her own novel at all. She had no idea about its sophisticated literary devices and its masterly composition. The conversation convinced him that most writers knew no more about literature than birds did about ornithology. It was the critic's task to analyse in depth what the author had written (Reich-Ranicki 1999, 340-343).

I do not share Marcel Reich-Ranicki's extreme view on the significance, or rather insignificance, of the author to the reading of their work. However, I consider concentration on the work and on its determinants as the most promising method for an archaeologist who wants to fathom the meaning of the remote past and the publications that describe it.

Hans-Georg Gadamer stated that the meaning of human life crystallizes around a decisive experience, not around the last one (Gadamer 1967). Paraphrasing his remark, I would say that Janusz Kruk's archaeological achievement should not be assessed by his last publication, which still remains to be written, but by his most important one, which is his $\mathrm{PhD}$ thesis Studia nad neolitem wyżyn lessowych (Studies of the Neolithic Settlement of the Loess Uplands; Kruk 1973).

This is Janusz Kruk's decisive publication for several reasons. I will mention the most important ones. The thesis is based on the assumption that functional relations between settlement (Fig. 3), economy and the environment (Fig. 4) are crucial to the historical process. Kruk has worked on that assumption ever since. In his $\mathrm{PhD}$ thesis, the human effect 


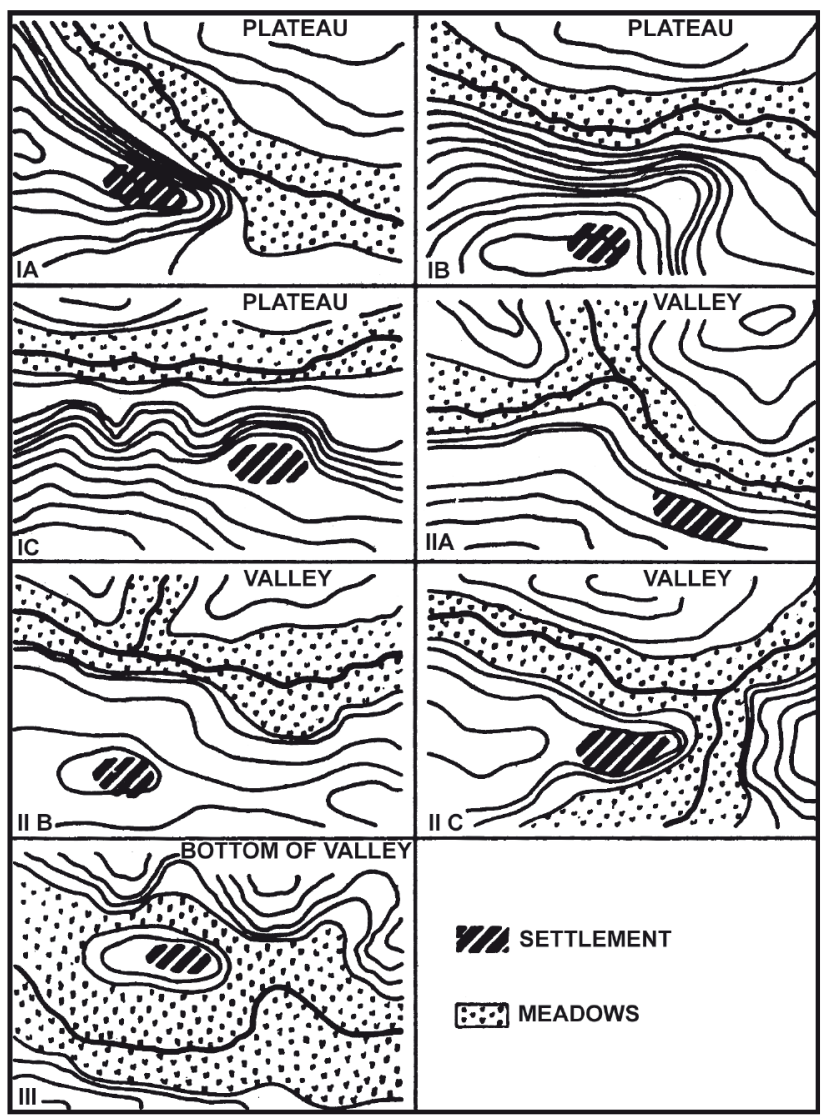

Fig. 3. Models of the topographic setting of Neolithic settlements on loess uplands (acc. to Kruk 1973)

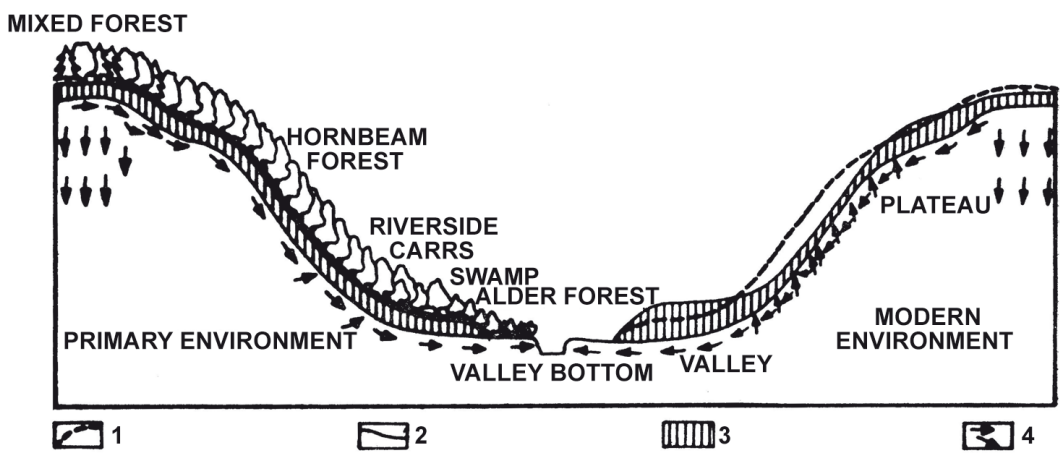

Fig. 4. A scheme of the ecology of primary environments on the loess uplands; 1 - primary form of the slope, 2 - contemporary form of the slope, 3 - depth of the soil, 4 - direction and intensity of groundwater movement (acc. to Kruk 1980b) 


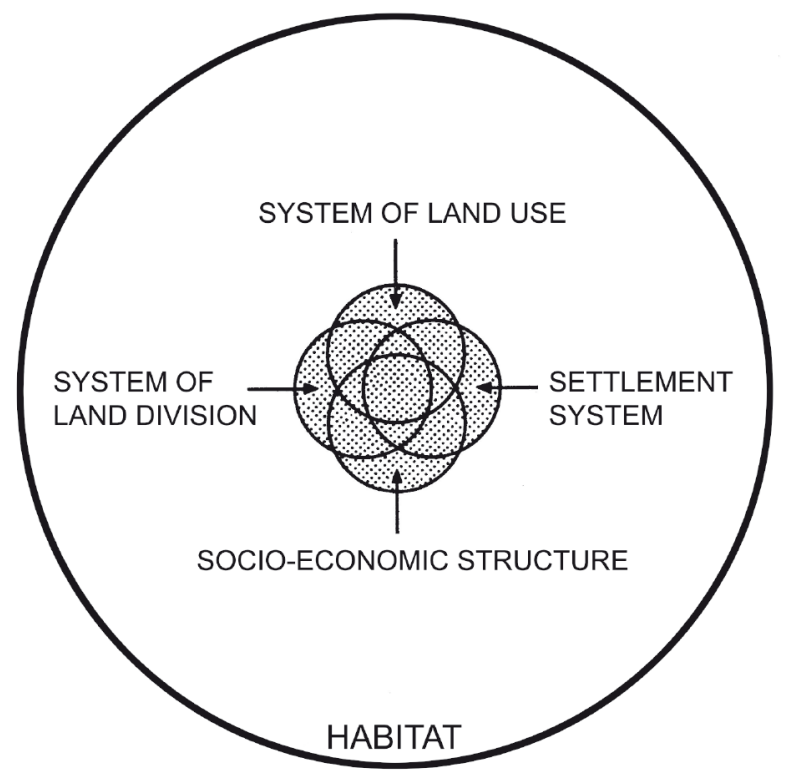

Fig. 5. Human occupation as a system with subsystems (acc. to Kruk 1980b)

on the environment, later termed "anthropopressure", is the key factor in economic, environmental and settlement changes. In all his subsequent texts, Kruk has focused on transformations of the environment caused by human activity; his analysis of the historical process has been restricted to the environment, economy and settlement. He has consistently omitted issues linked to society and spiritual culture, considering them inaccessible to scholarly research. He still holds that view today.

New elements in Kruk's subsequent publications strengthen the claims and propositions from his $\mathrm{PhD}$ thesis. The author defines selected notions more precisely and expands his source base, but his conclusions in crucial matters are of the same nature. In his postdoctoral thesis (Kruk 1980a), he broadens his materials concerning the environment and economy to include palaeobotanical and palaeozoological data, thus paying tribute to the standards of German settlement archaeology ( $c f$. Jankuhn 1977). He also makes references to the British school of palaeoeconomy (Vita-Finzi and Higgs 1970). Functional relations between settlement, economy and the environment are replaced with the relations of systems theory (Kruk 1980b - cf. Fig. 5), and spatial analyses are used to a greater extent (see Clarke 1977; Hodder and Orton 1976).

Slightly later, Kruk and Lesław Przywara defined botanical aspects of landscape zones (Kruk and Przywara 1983 - cf. Fig. 2, 4). In 1984, with Sarunas Milisauskas, Kruk introduced the notion of the "Bronocice circle" (Milisauskas and Kruk 1984 - Fig. 2), a method of analysing relations between the environment and economy taken from the British school 
of palaeoeconomy, employing, for example, the rule of minimization of effort (Johnson 1977). In 1996, with Stefan Alexandrowicz, Sarunas Milisauskas and Zbigniew Śnieszko he added geomorphological and malacological data to the source base and he included demographic analyses into research on the historical process (Kruk et al. 1996).

Later still, Kruk and Milisauskas developed the idea of central places and their evolution in the context of Funnel Beaker settlement in Małopolska (Kruk and Milisauskas 1999). In 2008, Kruk expanded the scope of his research to include other European areas (Kruk 2008), but it brought about no change in his premises or results.

Assuming the decisive role of Janusz Kruk's PhD thesis (1973) in the assessment of his method of studying prehistory or, more precisely, the Neolithic Age, it is worth going through the text itself to find the author's explicit comments on his aims, contexts, inspirations and borrowings. The purpose of the thesis is to determine the nature and scope of transformations carried out by primitive societies in the environment of the uplands of southern Poland (Kruk 1973, 7). The author planned to achieve that by studying Neolithic occupation and exploitation of that area (Kruk 1973, 7), i.e. by examining the settlement and economy in the context of the natural environment, with the settlement serving as an introduction to the study of the basis for the economy (Kruk 1973, 7, 10), i.e. the basis for subsistence.

Janusz Kruk did not name his inspirations for the choice of his aims and research method. He even skipped Eugene Odum's influential book on the fundamentals of ecology (Odum 1971). He rarely refers to other researchers, mentioning only Tadeusz Wiślański's publication $(1969,219)$ as helpful to him in broadening his analysis of the methods of land exploitation, i.e. economy in the context of the environment. However, his debt to Graham Clark $(1957,17)$ as regards functional relations between settlement and economy (culture) on the one hand, and the environment (nature) on the other, is unquestionable. Stanisław Kurnatowski (1966) may be viewed as another obvious influence, because of the key role Kruk ascribes to settlement analysis.

Surface survey has been presented as an important element of field investigation aimed at reconstructing a settlement network with its environmental determinants (Kruk 1973, 23-34). The significance of such surveys was shown earlier by archaeologists from the Poznań centre, particularly by Stanisław Kurnatowski (1963) and Tadeusz Wiślański (1966).

The drawing up and realisation of the research project outlined above was entrusted to Krakow's Unit of Małopolska Archaeology of the Institute of the History of Material Culture at the Polish Academy of Sciences (currently, the Centre for the Archaeology of Hills and Uplands of the Institute of Archaeology and Ethnology of the Polish Academy of Sciences). The framework of an analogous programme had been prepared at Poznań's Unit of Wielkopolska Archaeology of the Institute of the History of Material Culture at the Polish Academy of Sciences, in 1953-1954 (Wiślański 1969, 7-12). The first stage of the implementation of the programme was crowned with Tadeusz Wiślański's well-known 
study Podstawy gospodarcze plemion neolitycznych $w$ Polsce pótnocno-zachodniej (The economic basis of Neolithic tribes in north-western Poland), finished in December 1967 (Wiślański 1969, 7-8).

The obvious question is why the project was granted to Kraków and not to Poznań, though the Poznan centre already had considerable achievements in that field.

The decision taken by the head of the Institute of the History of Material Culture in Warsaw seems to have been influenced by the arrival of Sarunas Milisauskas, a Fulbright scholar, in Poland in 1965. At first, Milisauskas intended to organise a research project in collaboration with Konrad Jażdżewski, but the plan failed due to Jażdżewski's opposition to the Polish communist authorities. His position was euphemistically characterised by Jan Machnik as a lack of the necessary pragmatism (Woźny 2014, 287, 288). Consequently, James Griffin, Milisauskas' superior and teacher, turned to Witold Hensel, the head of the Institute, in order to establish cooperation. Details of that undertaking (19661980) have been given in a number of publications (see Hensel and Milisauskas 1985; Milisauskas 2015, 316-318), and its effects are still noticeable today. Hensel referred the American archaeologists to Kraków. Milisauskas later described his co-operation with Janusz Kruk as fundamental to his research in Poland (Milisauskas 2015, 318). The project Studia osadnicze nad neolitem wyżyn lessowych (Studies of the Neolithic Settlement of the Loess Uplands; $c f$. Kruk 1973) was, therefore, a natural and necessary complement to the Polish-American project Chronologia oraz gospodarcza i społeczna organizacja społeczności neolitycznych i wczesnobrąowych w Polsce potudniowo-wschodniej (Chronology and socioeconomic organisation of Neolithic and Early Bronze communities in south-eastern Poland).

Janusz Kruk began his field investigation, an element of his archaeological research, in 1967; at the same time, excavations started in the loess areas near Krakow as part of the Polish-American co-operation. The collaboration between Kruk and Milisauskas had not been planned in advance. It resulted from various factors, mostly those from outside their discipline, but it proved extremely fruitful, particularly because it led to the development of one of the most effective trends in Polish archaeology.

One major component of Janusz Kruk's settlement archaeology is the concept of anthropopressure as a prime mover in the historical process. People reproducing conditions of their existence by managing their resources bring about changes in their environment. These environmental changes, in turn, determine and seriously affect changes in the strategies of occupation and exploitation of the settled area.

The concept of anthropopressure seems even more original when we remember that then, no less than now (e.g. Gronenborn 2010 and many others), the dominant theory was that the historical process is to a greater or lesser extent under the one-sided influence of climatic changes external to human communities. Kruk (1973, 120-128), however, perceives no relation between the trajectories of climatic changes and those of changes in economy and settlement. In this, he disagrees explicitly with German anthropogeography, 
particularly in regard to Robert Gradmann's Steppenheidentheorie (1901; 1936; Kruk 1973, 123, 124; cf. also Kadrow 2013, 526). However, John Bintliff sees serious anthropogeographical inspirations in Kruk's settlement studies (Bintliff 2013, 22).

Kruk's PhD thesis and subsequent publications do not name the sources that may have inspired that concept. One hint can be found in the following sentence, written in a paper from 1983: "people seem to have forgotten too long ago that the earth had been given to them only to use, not to use up or, even less, to ravage" (Kruk and Przywara 1983, 41). The remark, given without quotation marks or reference to its source, is a literal quotation from the Polish version of a book by ecologist I.G. Simmons (Simmons 1979, 44). Simmons points to the original author of that sentence, Georg Perkins Marsh (1801-1882), an American defender of nature and a precursor of ecological movements, the author of Man and nature, or Physical geography as modified by human action (Marsh 1865). The title alludes to one of Marsh's key points: the influence of human action on the environment. Marsh wrote his book as a warning against using up or ravaging the earth. Corresponding with this idea, the Neo-Malthusian paradigm became, at the same time, a source of belief in the significant impact of humans on the environment in American archeology (cf. Ucko and Dimbleby 1969; Flannery 1972).

It is no surprise that the renaissance of Marsh's thought was contemporaneous with the activities of the Club of Rome, founded in 1968. What may be surprising is the general lack of response to the idea of anthropopressure in continental European archaeology except for Janusz Kruk's research. The first report by the Club of Rome, The Limits to Growth, was published no sooner than 1972 (Maedows et al. 1972), but it was preceded by an energetic promotional campaign that lasted several years. The report focused on the limited natural resources and the destruction of the natural environment due to demographic growth. Kruk's PhD thesis was written in the same period. The inspiration for his notion of anthropopressure, therefore, seems quite clear.

Another major trait of Janusz Kruk's settlement archaeology is, paradoxically, his interest in the cultural determinants of turning points in settlement processes or, more broadly, the historical process. In periods of stabilisation, the historical process is determined by interdependent changes in economy and the environment, reflected in changes in settlement. In the rare, but decisive moments of thorough transformation, however, cultural factors come to the fore. This was shown, for example, by the "volitional" decision (i.e. undetermined by external environmental or political factors) taken by the earliest migrants from the Danube area (the Linear Pottery population) to colonize the Polish loesses, or by the equally "volitional" decision of the Funnel Beaker population from the European Lowland to settle the loess uplands in Małopolska. The combination of the systematic interplay of interdependent environmental and economic factors with the effects of such "volitional" decisions in prehistoric communities is reminiscent of Vidal de la Blanche's geographical possibilism (1903; $c f$. also Geremek and Kula 2004), implemented effectively, for example, by Fernand Braudel in his research (2004). 
Janusz Kruk has never quoted any geographical or historical publications related with the notion of possibilism, but he has read Tadeusz Wiślański (1969), who cites Witold Kula (1963), who was well-versed in Vidal de la Blanche's and Fernand Braudel's theories. The presumptive inspiration may have been unconscious, but this does not mean it was absent or insignificant.

Kruk's settlement archaeology also includes such essential traits as modelling the past, lack of interest in isolated objects, phenomena or events, and concentration on long-term processes and general categories, e.g. landscape zones, central places, settlement patterns, the size of the population, strategies of land exploitation, etc. This is evidenced by all his work.

However, some propositions and declarations resulting from a compromise with the beliefs dominant in certain academic circles ( $c f$. remarks in Bourdie and Wacquant 2001, 32), and which neither express nor reflect the real character of one's research, may sometimes lead to misguided opinions. This happens when comprehensive, thoroughgoing appraisal of scholarly achievement is replaced by the fetishization of unconnected statements taking the form of not necessarily adequate manifestos.

In his postdoctoral thesis, Janusz Kruk wrote: "The aim has been to examine in detail several groups of sources and thus to identify tangible evidence of Neolithic subsistence strategies. Filling in the considerable shortage of information, made explicit by the analysis, with suggestions supported by so-called non-source based knowledge or solely by a scholar's intuition has been in fact a departure from the adopted method" (Kruk 1980a, 324). This is a clear example of a superficial tribute paid to trends predominating in Kraków at that time (cf. e.g. Godłowski 1960).

Taking that statement as an expression of Janusz Kruk's real intentions, Janusz OstojaZagórski commented disparagingly: “contrary to S. Tabaczyński’s suggestion ... inductionism in its empirical form, which has already acquired a classical status, does not belong to the past any more. In Central-European archaeology, it is still the basic tool of methodological reflection, as demonstrated by Kruk's confessions closing his innovative, it would seem, dissertation on Neolithic economy" (Ostoja-Zagórski 1988, 253). And he added: "Inductionism, then, has not lost its importance. On the contrary, it has taken the form of logical empiricism and is gaining new followers" (Ostoja-Zagórski 1988, 253).

It would be difficult to find a more obvious example of a gap between Ostoja-Zagórski's opinion and the real character of Kruk's archaeological achievement.

Janusz Kruk's approach is also characterised by his exclusive concentration on "scientifically" identifiable aspects of reality and by his consistent shunning of sociocultural issues, "world images", ritualization etc. Despite the lack of references to specific archaeological publications, his intellectual debt to Graham Clark (1939) is unquestionable on that point.

Although the basis of Janusz Kruk's settlement archaeology is functional, processual tendencies have become, with time, more pronounced in his research (e.g. Kruk 1980b). In 
formal terms, a prominent trait of his approach is the prevalent lack of references to his inspirations. John Bintliff $(2013,22)$ also thinks similarly, pointing among others to the lack of references to the work of Eugene P. Odum (1971), which clearly influenced the content of Kruk's doctoral dissertation. However, the obtained results have proved so important that one may disregard the question of whether this is a function of Kruk's conscious self-creation or of his becoming subconsciously permeated with ideas drawn from personal contacts and informal discussions, rather than assimilating them in library sessions.

\section{Final remarks}

In popular, unofficial statements (I do not know any publication that would clarify this discursively) one may come across the thesis that the scope of serious inspirations of Kruk's work is exhausted by the references therein to the scientific achievements of Tadeusz Wiślański (Wiślański 1969). This thesis is consistent with the tendency - popular especially among positivists - to identify the sense of the work with the author's intention (Compagnon 2010, 37). It could be reduced to the opinion that, with regard to sources of intellectual inspiration and questions about materials and method, one should simply ask the author (in this case Kruk). As a result of this approach, we would receive some "proven" knowledge on the subject. In contrast, inquiries based on the interpretation of the work itself are supposed to be burdened with a flaw of arbitrariness.

The desire to achieve full objectivity in scientific research is commendable. The problem is that it is also difficult to achieve. This is demonstrated not only by the position and achievements of the previously mentioned schools of literary criticism (formalism, New Criticism, structuralism and theory of "the Death of the Author"), but above all by a relationship discovered by Pierre Bourdieau in which some propositions and declarations in scientific activity result from a compromise with beliefs dominant in certain academic circles ( $c f$. remarks in Bourdie and Wacquant 2001, 32), and which neither express nor reflect the real character of one's research ( $c f$. also Kadrow 2014, 15). This situation explains Janusz Ostoja-Zagórski's (1988) aforementioned false trail in the interpretation of the theoretical foundations of Kruk's settlement studies.

The practice of selectively citing inspirational publications is neither a scandal, nor is it rarely found in scientific literature. To some extent, it results from the need/necessity to enter into the beliefs that dominate in a given environment. For example, according to Bintliff $(2013,23)$, the concept of ,community areas” in Czech settlement studies was inspired in part by Kruk (1973; 1980a); however, in the program article of Evžen Neustupný (1991) there is no mention of this.

In 1960 s and at the turn of the 1960 s and 70s, there was a revival in settlement research in the East (e.g. Gurba 1961; Bibikov 1965; Kruk 1973) and the West (Ucko and Dimbleby 1969; Flannery 1972 etc.), which resulted in some unification of research issues. 
This type of unification, however, probably stemmed more from global sensitivity to politically driven ecologism than from the same theoretical traditions.

Nearly fifty years ago David Clarke called for clear theoretical assumptions in every publication (Clarke 1973). Kruk fulfilled his duty and outlined the methods he used (Kruk 1973) exceptionally clearly, as per the customs in Polish archeology. In his work, he anticipated the position of David Clarke, which in modern science, including archeology, seems obvious and necessary.

The problem in the case of Kruk's work is not the lack of theory and method, but the lack of information about their sources. The purpose of this article is to reconstruct inspirations and intellectual determinants, which, according to accepted theory, usually escape the consciousness of the creator of both an artistic and scientific work.

This article is an extended version of the text published in Polish in the 54th volume of the journal Fontes Archaeologici Posnanienses - cf. Kadrow 2018.

\section{References}

Barthes R. 2006. Śmierć autora. In A. Burzyńska and M. P. Markowski (eds), Teorie literatury XX wieku. Antologia. Kraków: Znak, 355-358.

Bibikov S. N. 1965. Khozyaistvenno-ekonomicheskii kompleks razvitogo Tripolya. Sovetskaya arkheologia 1, 48-62.

Bintliff J. 2013. A Brief Commentary of Micro-Landscape Studies in Honour of Janusz Kruk. In S. Kadrow and P. Włodarczak (eds), Environment and subsistence - forty years after Janusz Kruk's „Settlement studies...” (= Studien zur Archäologie in Ostmitteleuropa/Studia nad Pradziejami Europy Środkowej 11). Rzeszów, Bonn 2013: Institute of Archaeology, Rzeszów University \& Verlag Dr. Rudolf Habelt GmbH, 21-25.

Bourdie P. and Wacquant L. J. D. 2001. Zaproszenie do socjologii refleksyjnej (= Terminus 21). Warszawa: Oficyna Naukowa.

Braudel F. 2004. Morze Śródziemne i świat śródziemnomorski w epoce Filipa II. Warszawa: Książka i Wiedza.

Compagnon A. 2010. Demon teorii. Literatura a zdrowy rozsq̨dek. Gdańsk: słowo/obraz terytoria.

Clark J. G. D. 1939. Archaeology and Society. London: Methuen.

Clark J. G. D. 1957. Europa Przedhistoryczna. Warszawa: Wiedza Powszechna.

Clarke D. 1973. The Loss of Innocence. Antiquity 47, 6-18.

Clarke D. L. 1977. Spatial Information in Archaeology. In D. L. Clarke (ed.), Spatial Archaeology. New York: Academic Press, 1-32.

Diachenko A., Kruk J. and Milisauskas S. 2016. What does the bell-distribution hide? Spatial behavior and demographic development of the Funnel Beaker Culture poppulations in Bronocice region, Poland. Sprawozdania Archeologiczne 68, 25-38. 
Flannery K. V. 1972. The Cultural Evolution of Civilizations. Annual Review of Ecology and Systematics 3, 399-426.

Gadamer H.-G. 1967. Das Problem der Geschichte in der neueren deustchen Philosophie. In Kleine Schriften 1. Philosophie, Hermeneutik. Tübingen: Verlag J. C. B. Mohr (Siebeck), 1-10.

Geremek B. and Kula W. 2004. Fernand Braudel i „Morze Śródziemne”. In F. Braudel, Morze Śródziemne i świat śródziemnomorski w epoce Filipa II. Warszawa: Książka i Wiedza, 6-13.

Godłowski K. 1960. Studia nad stosunkami społecznymi w okresach późnolateńskim i rzymskim $w$ dorzeczu Odry $i$ Wisły. Wrocław: Zakład Narodowy im. Ossolińskich.

Gradmann R. 1901. Das mitteleuropäische Landschaftsbild nach seiner geschichtlicher Entwicklung. Geographische Zeitschrift 7, 361-377.

Gradmann R. 1936. Vorgeschichtliche Landwirtschaft und Besiedlung. Geographische Zeitschrift 42, 378-386.

Gronenborn D. 2010. Climate, crises, and the „neolithisation” of Central Europe between IRD-Events 6 and 4. In D. Gronenborn and J. Petrasch (eds), Die Neolithisierung Mitteleuropas. Internationale Tagung, Mainz 24. bis 26. Juni 2005. Mainz: Verlag der Römisch-Germanischen Zentralmuseums, 61-80.

Gurba J. 1961. Neolithic Settlements in the Lublin Loess Upland. Annales UMCS, sec. B. 15, 211-233.

Hensel W. and Milisauskas S. 1985. Excavations of Neolithic and Early Bronze Age Sites in SouthEastern Poland. Wrocław: Zakład Narodowy im. Ossolińskich.

Hodder I. and Orton C. 1976. Spatial Analisis in Archaeology. Cambridge: Cambridge University Press.

Howell J. 1983. Settlement and Economy in Neolithic France (= British Archaeological Reports. International Series 157). Oxford: Archaeopress.

Jankuhn H. 1977. Einführung in die Siedlungsarchäologie. Berlin-New York: Walter de Gruyter.

Johnson G. A. 1977. Aspects of Regional Analysis in Archaeology. Annual Review of Anthropology 6, 479-508.

Kadrow S. 1992. Settlement Archaeology after Janusz Kruk. Poročilo o raziskovanju paleolita, neolita in eneolita $v$ Sloveniji 20, 49-55.

Kadrow S. 2010. Antropopresja, neodarwinizm, globalne zmiany klimatyczne i teoria ewolucji społecznej Habermasa. In S. Czopek and S. Kadrow (eds), Mente et rutro. Studia archaeologica Johanni Machnik viro doctissimo octogesimo vitae anno ab amicis, collegis et discipulis oblate. Rzeszów: Instytut Archeologii UR, 61-90.

Kadrow S. 2013. Regional research in archaeology in the light of selected traditions of geographical studies. In S. Kadrow and P. Włodarczak (eds), Environment and subsistence - forty years after Janusz Kruk's „Settlement studies...” (= Studien zur Archäologie in Ostmitteleuropa) Studia nad Pradziejami Europy Środkowej 11). Rzeszów, Bonn 2013: Institute of Archaeology, Rzeszów University \& Verlag Dr. Rudolf Habelt GmbH, 525-531.

Kadrow S. 2014. TransCarpathian Contacts in the Neolithic and the Early Bronze Age. In T. L. Kielnin, P. Valde-Nowak, M. Korczyńska, K. Cappenberg and J. Ociepka (eds), Settlement, Communication and Exchange around the Western Carpathians. International Workshop held at the 
Institute of Archaeology Jagiellonian University, Kraków October 27-28, 2012. Oxford 2014: Archaeopress Archaeology, 13-26.

Kadrow S. 2018. Archeologia osadnicza Janusza Kruka - inspiracje i uwarunkowania. Fontes Archaeologici Posnanienses 54, 191-197.

Kadrow S. and Machnik J. 2001. Badania nad osadnictwem neolitycznym i wczesnobrązowym na obszarach lessowych Małopolski. In J. K. Kozłowski and E. Neustupný (eds), Archeologia przestrzeni. Metody i wyniki badań struktur osadniczych $w$ dorzeczach górnej Łaby i Wisty. Kraków: Polska Akademia Umiejętności, 111-125.

Kruk J. 1973. Studia nad neolitem wyżyn lessowych. Wrocław, Warszawa, Kraków, Gdańsk: Zakład Narodowy im. Ossolińskich.

Kruk J. 1980a. Gospodarka $w$ Polsce południowo-wschodniej $w$ V-III tysiacleciu p.n.e. Wrocław: Ossolineum.

Kruk J. 1980b. Remarks concerning the Geography of Settlement of Prehistoric Communities. In R. Schild (ed.), Unconventional Archaeology. New Approaches and Golas in Polish Archaeology. Wrocław: Zakład Narodowy im. Ossolińskich, 17-32.

Kruk J. 2008. Wzory przeszłości. Studia nad neolitem środkowym i późnym. Kraków: Instytut Archeologii i Etnologii PAN.

Kruk J., Milisauskas S., Alexandrowicz S. and Śnieszko Z. 1996. Osadnictwo i zmiany środowiska naturalnego wyżyn lessowych. Studium archeologiczne i paleogeograficzne nad neolitem $w$ dorzeczu Nidzicy. Kraków: Instytut Archeologii i Etnologii PAN.

Kruk J. and Przywara L. 1983. Roślinność potencjalna jako metoda rekonstrukcji naturalnych warunków rozwoju społeczności pradziejowych. Archeologia Polski 28(1), 19-50.

Kula W. 1963. Problemy i metody historii gospodarczej. Warszawa: PWN.

Kurnatowski S. 1963. Uwagi o kształtowaniu się stref zasiedlenia dorzecza Obry w czasie od środkowego okresu epoki brązu do późnego średniowiecza. Archeologia Polski 8, 181-221.

Kurnatowski S. 1966. Przemiany techniki uprawy roli w czasach między epoką brązową i wczesnym średniowieczem a rozmieszczenie stref zasiedlania. Studia z Dziejów Gospodarstwa Wiejskiego 8, 92-99.

Machnik J. 2015. A Brief Response to S. Milisauskas. Sprawozdania Archeologiczne 67, 329-332.

Marsh G. P. 1865. Man and nature, or Physical geography as modified by human action. New York: Charles Scribner [Reprinted 1965, Harvard: Belknap Press].

Meadows D. H., Meadows D. L., Randers J. and Behrens W. W. 1972. The Limits to Growth: a Report to the Club of Rome's Project on the Predicament of Mankind. New York: Universe Books.

Milisauskas S. 2015. Myth Making by Jan Machnik: the American and Polish Cooperative Archaeological Project 1966-1978. Sprawozdania Archeologiczne 67, 315-327.

Milisauskas S. and Kruk J. 1984. Settlement Organization and the Appearance of Low Level Hierarchical Societies during the Neolithic in the Bronocice Microregion, Southeastern Poland. Germania 62(1), 1-30.

Neustupný E. 1991. Community areas of prehistoric farmers in Bohemia. Antiquity 65, 321-331.

Odum E. P. 1971. Fundamentals of Ecology. Philadelphia: W. B. Saunders Company. 
Ostoja-Zagórski J. 1988. Empiria i teoria w badaniach archeologicznych. Archeologia Polski 33(2), 247-272.

Reich-Ranicki M. 1999. Mein Leben. München: Deutscher Taschenbuch Verlag.

Simmons G. I. 1979. Ekologia zasobów naturalnych. Warszawa: PWN.

Ucko P. J. and Dimbleby G. W. (eds) 1969. The domestication and exploitation of plants and animals. Chicago: Aldine.

Vidal de la Blache P. 1903. Tableau géographique de la France. Paris: Hachette.

Vita-Finzi C. and Higgs E. S. 1970. Prehistoric Economy in the Mount Carmel Area of Palestine: Site Catchment Analysis. Proceedings of the Prehistoric Society 36, 1-37.

Walser M. 2002. Tod eines Kritikers. Frankfurt am Main: Suhrkamp Verlag.

Wiślański T. 1966. Próba zarysowania podstawowych form osadnictwa neolitycznego w Polsce północno-zachodniej. Archeologia Polski 10, 474-505.

Wiślański T. 1969. Podstawy gospodarcze plemion neolitycznych $w$ Polsce pólnocno-zachodniej. Wrocław, Warszawa, Kraków: Zakład Narodowy im. Ossolińskich.

Włodarczak P. 2013. The lost settlements - one from the visible problems in the research on the Final Neolithic in southern Poland. In S. Kadrow and P. Włodarczak (eds), Environment and subsistence - forty years after Janusz Kruk's „Settlement studies...” (= Studien zur Archäologie in Ostmitteleuropa/Studia nad Pradziejami Europy Środkowej 11). Rzeszów, Bonn 2013: Institute of Archaeology, Rzeszów University \& Verlag Dr. Rudolf Habelt GmbH, 173-184.

Woźny M. 2014. Między pokoleniami. Jak Jaśko miast ułanem archeologiem zostat. Wywiad rzeka. Z Profesorem Janem Machnikiem rozmawia Marzena Woźny. Rzeszów: Wydawnictwo Uniwersytetu Rzeszowskiego. 
